\title{
Progranulin axis and recent developments in frontotemporal lobar degeneration
}

\author{
Alexandra M Nicholson, Jennifer Gass, Leonard Petrucelli and Rosa Rademakers*
}

\begin{abstract}
Frontotemporal lobar degeneration (FTLD) is a devastating neurodegenerative disease that is the second most common form of dementia affecting individuals under age 65. The most common pathological subtype, FTLD with transactive response DNA-binding protein with a molecular weight of $43 \mathrm{kDa}$ inclusions (FTLD-TDP), is often caused by autosomal dominant mutations in the progranulin gene (GRN) encoding the progranulin protein (PGRN). GRN pathogenic mutations result in haploinsufficiency, usually by nonsense-mediated decay of the mRNA. Since the discovery of these mutations in 2006, several groups have published data and animal models that provide further insight into the genetic and functional relevance of PGRN in the context of FTLD-TDP. These studies were critical in initiating our understanding of the role of PGRN in neural development, degeneration, synaptic transmission, cell signaling, and behavior. Furthermore, recent publications have now identified the receptors for $P G R N$, which will hopefully lead to additional therapeutic targets. Additionally, drug screens have been conducted to identify pharmacological regulators of PGRN levels to be used as potential treatments for PGRN haploinsufficiency. Here we review recent literature describing relevant data on GRN genetics, cell culture experiments describing the potential role and regulators of PGRN in the central nervous system, animal models of PGRN deficiency, and potential PGRN-related FTLD therapies that are currently underway. The present review aims to underscore the necessity of further elucidation of PGRN biology in FTLD-related neurodegeneration.
\end{abstract}

*Correspondence: rademakers.rosa@mayo.edu Department of Neuroscience, Mayo Clinic Jacksonville, 4500 San Pablo Road, Jacksonville, FL 32224, USA

\section{Introduction}

Frontotemporal lobar degeneration (FTLD) is a progressive neurodegenerative disorder accounting for 5 to $10 \%$ of all dementia patients [1]. After Alzheimer's disease, FTLD is the most common cause of early-onset neurodegenerative dementia in cases before 65 years of age [2]. As the name suggests, FTLD patients develop severe atrophy of the frontal and temporal lobes. Consequently, associated neurodegeneration leads to various symptoms that are clinically organized into different subtypes. The first subtype, behavior variant frontotemporal dementia, is associated with behavioral changes and personality dysfunction $[3,4]$. Secondly, FTLD patients can present with language dysfunctions, or primary progressive aphasia in particular, with nonfluent/agrammatic variant primary progressive aphasia and semantic primary progressive aphasia $[3,5]$. Some patients display motor neuron impairments co-associated with frontotemporal dementia, termed frontotemporal dementia motor neuron disease, resembling amyotrophic lateral sclerosis (ALS) [6].

Neuropathologically, FTLD patients are divided into two main classes: those with tau-positive inclusions, and those with ubiquitin-positive but tau-negative inclusions. The ubiquitinated protein inclusions in FTLD with ubiquitin-positive inclusions are comprised of the fusedin sarcoma protein in some cases; however, the majority of FTLD brains with ubiquitin-positive inclusions contain transactive response DNA-binding protein with a molecular weight of $43 \mathrm{kDa}$ (TDP-43) in the inclusions, now referred to as FTLD-TDP [7]. TDP-43, an RNA/DNA binding protein with multiple roles in RNA metabolism and transcriptional repression, becomes hyperphosphorylated, is cleaved into C-terminal fragments, and translocates from the nucleus to the cytoplasm in FTLDTDP patients [8,9]. Moreover, TDP-43-positive inclusions are also found in ALS, suggesting that ALS and FTLD-TDP constitute a broad disease continuum [8].

FTLD has strong genetic influence, with 10 to $40 \%$ of patients having a positive family history [10]. Mutations in the microtubule-associated protein tau $(M A P T)$ gene were first identified to cause FTLD [11]. The brains of individuals with $M A P T$ mutations invariably present with hyperphosphorylated tau accumulation in affected 
brain regions characteristic of FTLD with tau pathology [12]. On the other hand, several genes have been shown to cause FTLD-TDP, such as mutations in genes encoding the valosin-containing protein $(V C P)[13,14]$, transactivation response DNA binding protein gene (TARDBP) $[15,16]$, or the recently identified chromosome 9 open reading frame 72 (C9ORF72) [17,18]. Additionally, in 2006 , the first mutations in the progranulin gene (GRN) were discovered after thorough examination of chromosome 17q21 [19,20]. Patients with GRN mutations also consistently present with intracellular TDP-43 accumulation upon autopsy, with primarily neuronal cytoplasmic inclusions as well as some neuronal intranuclear inclusions characteristic of FTLD-TDP type A as defined by the harmonized classification system $[8,21]$. Typically, GRN mutations include heterozygous frame-shift, nonsense, and splice-site alterations promoting premature termination of the coding sequence, subsequently leading to degradation of the mutant GRN mRNA via nonsensemediated decay [22]. The resulting 50\% loss in progranulin protein (PGRN) leads to disease by haploinsufficiency, suggesting that decreased PGRN levels might account for some patients' risk of developing FTLD-TDP. The role of PGRN in the central nervous system (CNS) and its link to TDP-43 pathology are currently being investigated, as addressed in the present review.

PGRN is recognized to date as a precursor protein composed of 7.5 tandem repeats separated by interlinked spacer regions [23]. A signal sequence allows PGRN to be secreted as a glycosylated $88 \mathrm{kDa}$ protein [24]. In the periphery, studies reveal that full-length PGRN is proteolytically cleaved into mature $6 \mathrm{kDa}$ granulins. This proteolytic processing is regulated by secretory leukocyte protease inhibitor (SLPI), which prevents cleavage by binding to PGRN itself or binding to and inhibiting the protease elastase [25]. Although it is unclear whether these mechanisms occur in the CNS, it has been hypothesized that elastase is released from activated microglia that cleaves extracellular PGRN, whereas SLPI is thought to be released from astrocytes thereby inhibiting this cleavage event $[26,27]$.

PGRN expression occurs in a variety of body tissues, including epithelial, immune and neuronal cells in adult rats and mice [28]. During development, PGRN is widely expressed in the forebrain, retinal ganglia, olfactory bulbs, and spinal cord [29]. In mature rodent brains, Pgrn expression is prominent in cerebellar Purkinje cells, pyramidal neurons throughout the cerebral cortex, and hippocampus, as well as activated microglia [29], suggesting roles in brain function. However, the main role of PGRN in the CNS remains relatively unknown, requiring additional work to understand PGRN-related mechanisms in the brain.
PGRN is a widely secreted growth factor involved in multiple biological functions such as cell growth and survival, embryogenesis, wound repair, and inflammation [24,29-31]. Recent work also established that PGRN and granulin E exhibit neurotrophic properties [32,33]. Collectively, PGRN has been linked to proper neuronal morphology and survival, inflammation, and TDP-43 pathology within the CNS. In the present review we highlight key findings related to PGRN and its role in FTLD-related neurodegeneration. Further, we discuss how PGRN might be a valuable target for developing potential FTLD-TDP treatments and therapies.

\section{Genetics of progranulin gene}

In 2006 GRN was identified as a second FTLD gene on chromosome 17q21, explaining the disease in the FTLD families linked to this region in which mutations in $M A P T$, located only $1.7 \mathrm{Mb}$ away from GRN, had been excluded $[19,20]$. Since then, 70 different GRN mutations have been identified in 232 families worldwide (Figure 1) $[34,35]$. The disease mechanism associated with GRN mutations is uniform; all mutations are heterozygous and result in the loss of $50 \%$ functional PGRN, causing disease through haploinsufficiency $[19,20]$. Most mutations lead to premature stop codons, either directly as a result of nonsense mutations or indirectly through a shift in the normal reading frame by splice-site mutations or small insertions and deletions, thereby inducing the degradation of mutant RNA by nonsense-mediated decay - although other mechanisms have been observed $[22,36,37]$. In addition to these typical GRN loss-offunction mutations, a large number of silent and missense mutations in GRN have also been reported, although their role in neurodegenerative disease pathogenesis has remained less clear [38]. In fact, most of these mutations have been observed in both patients and control individuals and are predicted to be nonpathogenic. Based on in vitro functional studies and in vivo PGRN expression analysis in patients carrying these mutations, however, four potential pathogenic missense mutations were identified that were uniquely seen in patients (p.C139R, p.P248L, p.R432C, and p.C521Y) (Figure 1) [39-44]. It is expected that at least some of these mutations cause disease through a partial loss of PGRN function, potentially by making neurons more vulnerable to neurodegeneration through subtle decreases in neurotrophic support.

The role of common GRN variants in the development of FTLD and related neurodegenerative diseases such as ALS, Alzheimer's disease, and Parkinson's disease has also been studied. In a series of pathologically confirmed FTLD-TDP patients, it was shown that carriers homozygous for the $\mathrm{T}$ allele of rs5848, located in a miRNA binding site in the 3' untranslated region of GRN, 


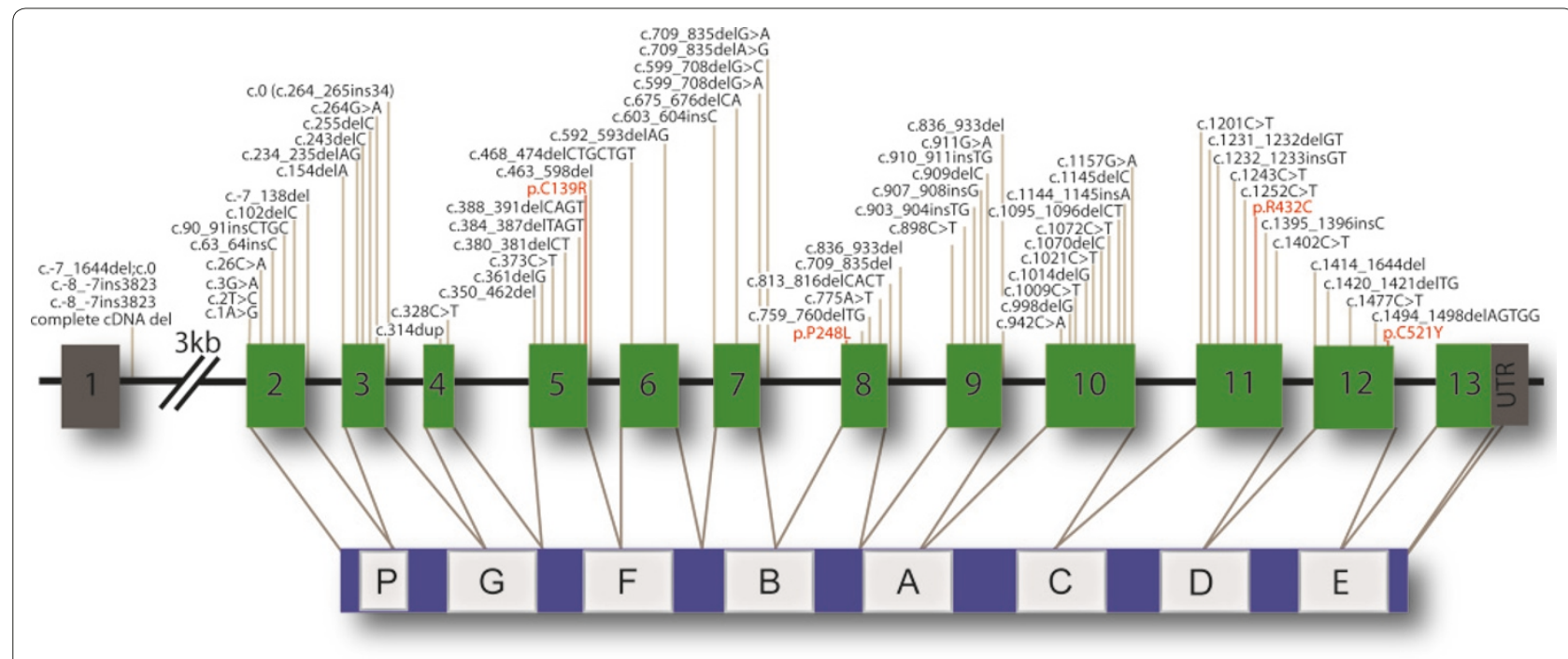

Figure 1. Overview of pathogenic loss-of-function mutations and potential pathogenic missense progranulin mutations in frontotemporal lobar degeneration. Mutations in the progranulin gene (GRN) are a common cause of frontotemporal lobar degeneration with transactivation response DNA binding protein molecular weight of $43 \mathrm{kDa}$ pathology (FTLD-TDP). Schematic representation of the genomic structure of GRN (top) and progranulin protein (PGRN) (bottom). The gray numbered boxes in the genomic structure indicate the noncoding exon 1 and the $3^{\prime}$ untranslated region; the green numbered boxes indicate coding exons 2 to 13. The white lettered boxes in PGRN refer to the individual granulin domains. A total of 70 different loss-of-function mutations scattered over all GRN exons, except exon 13, have been reported. These mutations are indicated with vertical brown lines on the GRN exons and listed above the exons with their cDNA numbering relative to the largest GRN transcript (GenBank accession number NM_002087.2). Four potential pathogenic missense mutations are indicated in red with their protein numbering according to the largest PGRN isoform GenPept accession number NP_002078.1).

have a 3.2-fold increased risk to develop FTLD-TDP compared with homozygous C-allele carriers [45]. In vitro studies confirmed that miR-659 can regulate PGRN expression, with miR-659 binding more efficiently to the high-risk T allele, thereby reducing PGRN levels. Although this genetic association could not be replicated in two series of largely clinical FTLD patients [46,47], these results are consistent with PGRN loss as the disease mechanism associated with FTLD-TDP. SNP rs5848 was also reported as a genetic risk factor for the development of hippocampal sclerosis in older people and for the development of Alzheimer's disease in a Taiwanese population $[48,49]$. Genetic association studies using several other common polymorphisms in the GRN genomic region further identified significant association of $G R N$ variants in Belgian and Finnish Alzheimer's disease populations [40,50], in Belgian and Dutch ALS populations [51], and in an Italian FTLD population [52]. Although additional studies are needed to fully resolve the role of GRN variability on the development of FTLD and related neurodegenerative disorders, these studies suggest an important role for PGRN dysfunction in a range of neurodegenerative diseases.

\section{Cell studies of progranulin protein}

The identification of disease-causing GRN mutations highlighted the importance of PGRN haploinsufficiency in the onset of FTLD-TDP and related TDP-43 proteinopathies. Understanding the role of PGRN in the CNS and its link to TDP-43 pathology has thus been the focus of many researchers in the neurodegenerative disease field. Since PGRN is known to be a secreted protein, experiments have been conducted to determine the potential role of extracellular PGRN in neuronal development and survival. Such studies have shown that addition of PGRN to stressed or PGRN-depleted neuronal cells promoted neurite outgrowth $[32,33,53,54]$. Moreover, the addition of SLPI abrogated these effects [32], suggesting SLPI as a likely regulator in PGRN processing and/or function. Two of these studies also described enhanced neuronal survival under stress conditions when recombinant PGRN was present $[32,53]$. The neuroprotective effects of PGRN might be due, at least in part, to the activation of cell signaling pathways involved in cell survival: such as the extracellular regulated kinase and/or phosphatidylinositol-3 kinase/Akt pathways [33,55-57]. Additional data for PGRN downstream signaling were recently published, indicating that PGRN loss induces the activation of the Wnt signaling pathway well before observable inflammation, microgliosis, or neurodegeneration [58]. More specifically, the Wnt receptor, frizzled family receptor 2 (Fzd2), was found to be upregulated in $\mathrm{Grn}^{-/-}$mice as a potential compensatory mechanism due to the role of Fzd2 as a neuroprotective 
factor [58]. These data not only implicate Fzd2 as a potential early marker of disease progression, but also suggest that therapeutic Fzd2 upregulation could be a promising FTLD treatment.

In addition to its role in neuronal cell survival and development, PGRN has also been speculated to play a role in excitotoxicity and synaptic transmission. Depletion of PGRN in cultured neurons by siRNA infection led not only to enhanced caspase- 3 activation, but also to vulnerability to $N$-methyl-D-aspartic acid-induced excitotoxicity [59]. Another recent publication presented data in which reduced PGRN levels caused a decrease in dendritic arborization, spine density, and presynaptic density that occurred concomitantly with an increase in synaptic vesicles per synapse - some of which was also observed in the brains of FTLD patients with GRN mutations [54]. These data indicated that while there is an overall decrease in the number of synapses under conditions of PGRN deficiency, glutamatergic transmission in the remaining synapses is enhanced, potentially as a compensatory mechanism. Taken together, PGRN seems to be a critical player in neuronal development and synaptic maintenance, both of which could result in the increased susceptibility to neuronal death, potentially leading to the neurodegeneration observed in patients with FTLD.

Although there is emerging evidence for an important role of PGRN in the CNS, the possible molecular mechanism(s) linking PGRN haploinsufficiency to TDP-43 dysfunction and/or pathology remain unclear; however, several publications have provided insight into such a mechanistic relationship. In 2007 Zhang and colleagues reported that PGRN suppression induced caspase-mediated cleavage of TDP-43 and mislocalization of TDP-43 from the nucleus to the cytoplasm in $\mathrm{H} 4$ cells, similar to that observed in the brains of FTLD-TDP patients [60]. On the other hand, this fragmentation and mislocalization was not observed in PGRN-deficient fibroblasts or other immortalized cell lines [42,56,61]. Nonetheless, PGRN-null cortical cultures did portray increased caspase activation and the production of TDP-43 cleavage products, although TDP-43 phosphorylation and solubility was unchanged [56]. Guo and colleagues additionally reported that PGRN knockdown in primary cortical cultures resulted in increased TDP-43 levels in the cytoplasm when these cells were cultured for 11 days post siRNA transfection [59]. The discrepancies that arise in studies of PGRN-induced TDP-43 dysfunction highlight the complexity and potentially cell-specific nature of the relationship between these two proteins. Further investigation is thus critical for uncovering the exact molecular mechanism underlying GRN haploinsufficiency and subsequent TDP-43 pathology in the context of FTLD.

\section{Progranulin protein receptors}

More information about the function of secreted proteins, such as PGRN, can be obtained by identifying their receptors. Such discoveries were made in the past year by three research groups.

Publications by Carrasquillo and colleagues and $\mathrm{Hu}$ and colleagues both independently identified sortilin-1 protein (SORT1), a member of the vacuolar proteinsorting defective domain with 10 conserved cysteine residues receptor family, as the first known receptor for PGRN [62,63]. SORT1 is an endocytic sorting receptor responsible for sorting its ligands between the Golgi apparatus and endosomes, as well as for targeting ligands to lysosomes [64]. As such, SORT1 overexpression significantly reduced extracellular levels of PGRN, after which SORT1 was found to bind the C-terminus of PGRN and deliver it to lysosomal compartments $[62,63,65]$. Interestingly, SORT1 was previously identified as the receptor for other neurotrophic factors in the brain, further supporting PGRN as a potential component of neuronal development and/or neuroprotection [66,67].

Shortly after these discoveries, Tang and colleagues reported their findings that showed TNF receptors as another group of proteins directly interacting with PGRN [68]. In fact, the presence of PGRN had an anti-inflammatory effect in PGRN-deficient mice due to outcompeting TNF $\alpha$ for receptor binding [68]. Collectively, the identification of SORT1 and TNF receptors as PGRN receptors will open new avenues in PGRN cell biology research and therapeutic development.

\section{Animal models of progranulin protein}

Development of animal models mimicking human disease is an invaluable tool for understanding the etiology as well as future therapies of disease. Since the first pathogenic GRN mutations were discovered, several Grn knockout animals have been generated in the hope of resolving our understanding of PGRN's involvement in neurodegeneration. The first Grn knockout mice were generated by Kayasuga and colleagues and displayed several features that correlated with FTLD [69]. First, $\mathrm{Grn}^{-/}$mice showed significant decreases in survival compared with their $\mathrm{Grn}^{+/+}$and $\mathrm{Grn}^{+/-}$littermates [58]. Initial behavioral characterization of this model further determined that juvenile male $\mathrm{Grn}^{-/-}$mice exhibited an enhanced aggressive behavior after repeated encounters with intruders [69]. Follow-up studies reported that this aggressive characteristic disappeared as $\mathrm{Grn}^{-/-}$mice mature into middle age, and $\mathrm{Grn}^{-/-}$mice began to exhibit decreased social interactions determined by a residentintruder test [58]. The differences in social interactions of these $\mathrm{Grn}^{-/}$mice are an important feature that mimics changes in social behavior observed in FTLD patients. Additionally, Morris water maze trials have revealed that 
older $\mathrm{Grn}^{-/-}$mice possess mildly impaired learning and memory performances, typical of later stages of FTLD [58]. Pathologically, $\mathrm{Grn}^{-/}$mice also display characteristics often observed in FTLD patients, including enhanced microglial activation, astrogliosis, and progressive accumulation of ubiquitin aggregates [58,70]. Ahmed and colleagues further analyzed these ubiquitin aggregates and found that they are largely composed of lipofuscin granules, which are recognized to form in response to mitochondrial stress and lysosomal injury [70]. Interestingly, these lipofuscin-containing granules are not observed in the brains of FTLD patients. Further, $\mathrm{Grn}^{-/-}$mice ubiquitin aggregates do not contain TDP-43, the main protein found in FTLD-TDP patient brain inclusions $[58,70]$.

Yin and colleagues independently generated a Grn knockout mouse model from which they discovered that Pgrn loss augmented inflammation, leading to an increase in the production of proinflammatory cytokines [71]. Various experiments revealed behavioral abnormalities in these mice, including increased depression-like and disinhibition-like behavior, in addition to impaired cognitive behavior in older animals, all of which are behavioral phenotypes observed in FTLD patients [72]. These mice also show an increase in microglial and astroglial activation with age, as well as ubiquitin staining [72]. Interestingly, this group determined that the ubiquitin aggregates within these animals contain TDP-43 pathology, which was not present in the previous animal model.

Alternative PGRN-deficient models have been developed in addition to the mouse model to further our knowledge of this protein using simpler organisms. Work in the nematode Caenorhabditis elegans brought new insight into the role of PGRN when data revealed that pgrn-1 mutants have unaltered apoptotic initiation but increased clearance of apoptotic cells [73]. This finding was also replicated in Pgrn-deficient mouse macrophages [73], suggesting that apoptosis kinetics is disrupted with PGRN loss across different species. One potential explanation for such data is that PGRN-null apoptotic cells undergo clearance before the cell has adequate time to recover, potentially leading to the increased neuronal loss observed in FTLD patients with PGRN insufficiency. Additionally, zebrafish studies showed that knockdown of zfPGRN-A, the ortholog to human PGRN, caused abnormal motoneuron development due to truncation and inappropriate branching, further demonstrating the neurotrophic properties of PGRN [74]. Similar to many cell culture experiments, however, PGRN loss in zebrafish did not affect the localization of the TDP-43 orthologs Tardbp and Tardbpl [42]. Even though several pathological and biochemical differences occur between the animal models and FTLD patients, many essential commonalities exist. It is expected that these and newly developed PGRN models will further improve our understanding of PGRN in disease and will serve as useful tools to investigate possible therapies for PGRN loss.

\section{Progranulin protein therapeutics}

The discovery of FTLD-causing mutations in GRN leading to haploinsufficiency has since implicated PGRN and its potential regulators as promising drug targets for FTLD-TDP treatments and therapies. Although there are no current drugs available to directly affect GRN mRNA or protein levels, one recent study is paving the way to such a discovery. Cenik and colleagues performed a chemical library screen in which the US Food and Drug Administration-approved suberoylanilide hydroxamic acid (SAHA) was identified as an enhancer of GRN transcription and subsequent PGRN expression [75]. Additionally, SAHA treatment restored normal PGRN levels in human cell lines derived from pathogenic GRN mutation carriers [75]. Although SAHA has been implicated in transcriptional regulation as a histone deacetylase inhibitor, the exact mechanism by which this acid contributes specifically to increased GRN expression remains to be elucidated.

PGRN levels could also possibly be increased by pharmacologically targeting proteins involved in its regulation and/or function. Two potential candidates are SORT1 and TNF receptors; however, no drugs have been developed to target these PGRN receptors. Nevertheless, encouraging findings were reported by Capell and colleagues, who screened for compounds capable of selectively increasing PGRN levels by inhibiting its proteolytic degradation [76]. Of the compounds screened, the alkalizing reagent bafilomycin $\mathrm{A} 1$ was the only drug to significantly increase intracellular and secreted PGRN levels. The authors showed that bafilomycin A1 increased PGRN levels in a posttranslational manner by selectively targeting vacuolartype $\mathrm{H}^{+}$-adenosine triphosphatase. Further, the data suggested that bafilomycin A1-dependent vacuolar-type $\mathrm{H}^{+}$-adenosine triphosphatase inhibition might increase intracellular and extracellular PGRN by neutralizing the $\mathrm{pH}$ of intracellular compartments and/or the extracellular space [76]; however, the direct mechanism by which vacuolar-type $\mathrm{H}^{+}$-adenosine triphosphatase inhibition leads to PGRN level alterations remains unclear.

Another protein identified as a potential PGRN regulator and, thus, a possible drug target is the transmembrane protein 106B (TMEM106B). Genetic variants in and near the TMEM106B gene were recently found in a genome-wide association study to protect individuals carrying pathogenic GRN mutations from developing FTLD-TDP [77]. The identified protective variants have been shown to correlate with increased plasma PGRN 
levels, as well as an increased age of onset in FTLD-TDP patients $[78,79]$. Since not all replication studies showed significance of these TMEM106B variants with FTLDTDP [80], additional experiments to assess the role of TMEM106B in FTLD-TDP are needed to validate this protein as a pharmacological target. Nonetheless, future drugs to modify TMEM106B levels and/or function could prove useful as an indirect means of altering PGRN levels in affected individuals.

\section{Conclusion}

Promising insights into the molecular mechanism of FTLD have been established since the discovery of GRN mutations. Since all known pathogenic GRN mutations cause haploinsufficiency, and since all GRN mutation carriers present with TDP-43 pathology in affected brain regions, PGRN levels and function probably play a predominant role in the FTLD-TDP disease subtype. The use of cell culture and animal modeling of PGRN depletion have uncovered only the surface of PGRN's role in the CNS. Although the link between PGRN and TDP-43 pathology still remains to be determined, recent studies have revealed critical information that could potentially lead to such a discovery. For example, some culture systems have begun to show that PGRN loss causes TDP-43 dysfunction, although not completely mimicking the dysfunction observed in vivo. Second, the identification of PGRN regulators such as TMEM106B and of the PGRN receptors such as SORT1 and TNF receptors will hopefully shed more light on PGRN intracellular signaling and additional therapeutic targets. In the last year, promising findings were reported implicating alkalizing agents and/or SAHA as possible drug candidates for increasing PGRN levels in FTLD patients. The continued search for more representative FTLD models and PGRN modifiers will prove imperative for the advancement of FTLD treatments and therapies.

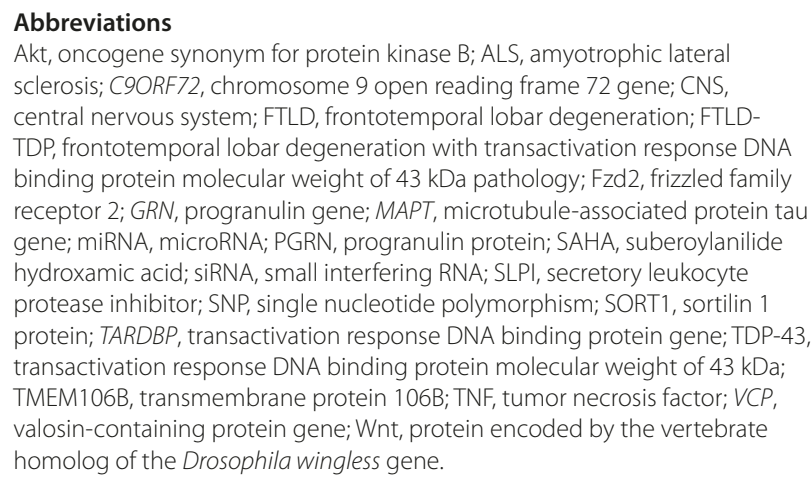

Competing interests

The authors declare that they have no competing interests.

\section{Acknowledgements}

The work in the authors' laboratories is supported by NIH grants P50AG16574-13, R01NS065782-3, R01AG026251-03A2-1, R01NS063964-2 and R01NS077402-1, the ALS Association, the ALS Therapy Alliance and the Consortium for Frontotemporal Dementia. AMN is funded by the Association for Frontotemporal Degeneration Postdoctoral Fellowship.

Published: 23 January 2012

References

1. Neary D, Snowden JS, Gustafson L, Passant U, Stuss D, Black S, Freedman M, Kertesz A, Robert PH, Albert M, Boone K, Miller BL, Cummings J, Benson DF: Frontotemporal lobar degeneration: a consensus on clinical diagnostic criteria. Neurology 1998, 51:1546-1554.

2. Ratnavalli E, Brayne C, Dawson K, Hodges JR: The prevalence of frontotemporal dementia. Neurology 2002, 58:1615-1621.

3. Boxer AL, Miller BL: Clinical features of frontotemporal dementia. Alzheimer Dis Assoc Disord 2005, 19(Suppl 1):S3-S6.

4. McKhann GM, Albert MS, Grossman M, Miller B, Dickson D, Trojanowski JQ: Clinical and pathological diagnosis of frontotemporal dementia: report of the Work Group on Frontotemporal Dementia and Pick's Disease. Arch Neurol 2001, 58:1803-1809.

5. Gorno-Tempini ML, Hillis AE, Weintraub S, Kertesz A, Mendez M, Cappa SF, Ogar JM, Rohrer JD, Black S, Boeve BF, Manes F, Dronkers NF, Vandenberghe R, Rascovsky K, Patterson K, Miller BL, Knopman DS, Hodges JR, Mesulam MM, Grossman M: Classification of primary progressive aphasia and its variants. Neurology 2011, 76:1006-1014.

6. Lomen-Hoerth C, Anderson T, Miller B: The overlap of amyotrophic lateral sclerosis and frontotemporal dementia. Neurology 2002, 59:1077-1079.

7. Mackenzie IR, Baker M, Pickering-Brown S, Hsiung GY, Lindholm C, Dwosh E, Gass J, Cannon A, Rademakers R, Hutton M, Feldman HH: The neuropathology of frontotemporal lobar degeneration caused by mutations in the progranulin gene. Brain 2006, 129:3081-3090.

8. Neumann M, Sampathu DM, Kwong LK, Truax AC, Micsenyi MC, Chou TT, Bruce J, Schuck T, Grossman M, Clark CM, McCluskey LF, Miller BL, Masliah E, Mackenzie IR, Feldman H, Feiden W, Kretzschmar HA, Trojanowski JQ, Lee VM: Ubiquitinated TDP-43 in frontotemporal lobar degeneration and amyotrophic lateral sclerosis. Science 2006, 314:130-133.

9. Buratti E, Baralle FE: The multiple roles of TDP-43 in pre-mRNA processing and gene expression regulation. RNA Biol 2010, 7:420-429.

10. The Genetics of FTD: Should You Worry? [http://www.theaftd.org/ frontotemporal-degeneration/genetics]

11. Hutton M, Lendon CL, Rizzu P, Baker M, Froelich S, Houlden H, PickeringBrown S, Chakraverty S, Isaacs A, Grover A, Hackett J, Adamson J, Lincoln S, Dickson D, Davies P, Petersen RC, Stevens M, de Graaff E, Wauters E, van Baren J, Hillebrand M, Joosse M, Kwon JM, Nowotny P, Che LK, Norton J, Morris JC, Reed LA, Trojanowski J, Basun H, et al:: Association of missense and 5'-splicesite mutations in tau with the inherited dementia FTDP-17. Nature 1998, 393:702-705.

12. Spillantini MG, Bird TD, Ghetti B: Frontotemporal dementia and Parkinsonism linked to chromosome 17: a new group of tauopathies. Brain Pathol 1998, 8:387-402.

13. Watts GD, Wymer J, Kovach MJ, Mehta SG, Mumm S, Darvish D, Pestronk A, Whyte MP, Kimonis VE: Inclusion body myopathy associated with Paget disease of bone and frontotemporal dementia is caused by mutant valosin-containing protein. Nat Genet 2004, 36:377-381.

14. Schroder R, Watts GD, Mehta SG, Evert BO, Broich P, Fliessbach K, Pauls K, Hans $\mathrm{VH}$, Kimonis $\mathrm{V}$, Thal DR: Mutant valosin-containing protein causes a novel type of frontotemporal dementia. Ann Neurol 2005, 57:457-461.

15. Borroni B, Bonvicini C, Alberici A, Buratti E, Agosti C, Archetti S, Papetti A, Stuani C, Di Luca M, Gennarelli M, Padovani A: Mutation within TARDBP leads to frontotemporal dementia without motor neuron disease. Hum Mutat 2009, 30:E974-E983.

16. Benajiba L, Le Ber I, Camuzat A, Lacoste M, Thomas-Anterion C, Couratier $P$, Legallic S, Salachas F, Hannequin D, Decousus M, Lacomblez L, Guedj E, Golfier V, Camu W, Dubois B, Campion D, Meininger V, Brice A: TARDBP mutations in motoneuron disease with frontotemporal lobar degeneration. Ann Neurol 2009, 65:470-473.

17. Dejesus-Hernandez M, Kocerha J, Finch N, Crook R, Baker M, Desaro P, Johnston A, Rutherford N, Wojtas A, Kennelly K, Wszolek ZK, Graff-Radford N, Boylan K, Rademakers R: De novo truncating FUS gene mutation as a cause of sporadic amyotrophic lateral sclerosis. Hum Mutat 2010, 31:E1377-E1389.

18. Renton AE, Majounie E, Waite A, Simon-Sanchez J, Rollinson S, Gibbs JR, Schymick JC, Laaksovirta H, van Swieten JC, Myllykangas L, Kalimo H, Paetau 
A, Abramzon Y, Remes AM, Kaganovich A, Scholz SW, Duckworth J, Ding J, Harmer DW, Hernandez DG, Johnson JO, Mok K, Ryten M, Trabzuni D, Guerreiro RJ, Orrell RW, Neal J, Murray A, Pearson J, Jansen IE, et al: A hexanucleotide repeat expansion in C9ORF72 is the cause of chromosome 9p21-linked ALS-FTD. Neuron 2011, 72:257-268.

19. Baker M, Mackenzie IR, Pickering-Brown SM, Gass J, Rademakers R, Lindholm C, Snowden J, Adamson J, Sadovnick AD, Rollinson S, Cannon A, Dwosh E, Neary D, Melquist S, Richardson A, Dickson D, Berger Z, Eriksen J, Robinson T, Zehr C, Dickey CA, Crook R, McGowan E, Mann D, Boeve B, Feldman H, Hutton M: Mutations in progranulin cause tau-negative frontotemporal dementia linked to chromosome 17. Nature 2006, 442:916-919.

20. Cruts M, Gijselinck I, van der Zee J, Engelborghs S, Wils H, Pirici D, Rademakers R, Vandenberghe R, Dermaut B, Martin JJ, van Duijn C, Peeters K, Sciot R, Santens P, De Pooter T, Mattheijssens M, Van den Broeck M, Cuijt I, Vennekens K, De Deyn PP, Kumar-Singh S, Van Broeckhoven C: Null mutations in progranulin cause ubiquitin-positive frontotemporal dementia linked to chromosome 17q21. Nature 2006, 442:920-924.

21. Mackenzie IR, Neumann M, Baborie A, Sampathu DM, Du Plessis D, Jaros E, Perry RH, Trojanowski JQ, Mann DM, Lee VM: A harmonized classification system for FTLD-TDP pathology. Acta Neuropathol 2011, 122:111-113.

22. Gass J, Cannon A, Mackenzie IR, Boeve B, Baker M, Adamson J, Crook R, Melquist S, Kuntz K, Petersen R, Josephs K, Pickering-Brown SM, Graff-Radford N, Uitti R, Dickson D, Wszolek Z, Gonzalez J, Beach TG, Bigio E, Johnson N, Weintraub S, Mesulam M, White CL, 3rd, Woodruff B, Caselli R, Hsiung GY, Feldman H, Knopman D, Hutton M, Rademakers R: Mutations in progranulin are a major cause of ubiquitin-positive frontotemporal lobar degeneration. Hum Mol Genet 2006, 15:2988-3001.

23. Bhandari V, Palfree RG, Bateman A: Isolation and sequence of the granulin precursor CDNA from human bone marrow reveals tandem cysteine-rich granulin domains. Proc Natl Acad Sci U S A 1992, 89:1715-1719.

24. He Z, Bateman A: Progranulin gene expression regulates epithelial cell growth and promotes tumor growth in vivo. Cancer Res 1999, 59:3222-3229

25. Zhu J, Nathan C, Jin W, Sim D, Ashcroft GS, Wahl SM, Lacomis L, ErdjumentBromage $H$, Tempst $P$, Wright $C D$, Ding A: Conversion of proepithelin to epithelins: roles of SLPI and elastase in host defense and wound repair. Cell 2002, 111:867-878

26. Eriksen JL, Mackenzie IR: Progranulin: normal function and role in neurodegeneration. J Neurochem 2008, 104:287-297.

27. Ahmed Z, Mackenzie IR, Hutton ML, Dickson DW: Progranulin in frontotemporal lobar degeneration and neuroinflammation. J Neuroinflamm 2007, 4:7.

28. Daniel R, He Z, Carmichael KP, Halper J, Bateman A: Cellular localization of gene expression for progranulin. J Histochem Cytochem 2000, 48:999-1009.

29. Daniel R, Daniels E, He Z, Bateman A: Progranulin (acrogranin/PC cellderived growth factor/granulin-epithelin precursor) is expressed in the placenta, epidermis, microvasculature, and brain during murine development. Dev Dyn 2003, 227:593-599.

30. Kessenbrock K, Frohlich L, Sixt M, Lammermann T, Pfister H, Bateman A, Belaaouaj A, Ring J, Ollert M, Fassler R, Jenne DE: Proteinase 3 and neutrophil elastase enhance inflammation in mice by inactivating antiinflammatory progranulin. J Clin Invest 2008, 118:2438-2447.

31. Xu SQ, Tang D, Chamberlain S, Pronk G, Masiarz FR, Kaur S, Prisco M, ZanoccoMarani T, Baserga R: The granulin/epithelin precursor abrogates the requirement for the insulin-like growth factor 1 receptor for growth in vitro. J Biol Chem 1998, 273:20078-20083.

32. Van Damme P, Van Hoecke A, Lambrechts D, Vanacker P, Bogaert E, van Swieten J, Carmeliet P, Van Den Bosch L, Robberecht W: Progranulin functions as a neurotrophic factor to regulate neurite outgrowth and enhance neuronal survival. J Cell Biol 2008, 181:37-41.

33. Gao X, Joselin AP, Wang L, Kar A, Ray P, Bateman A, Goate AM, Wu JY: Progranulin promotes neurite outgrowth and neuronal differentiation by regulating GSK-3ß. Protein Cell 2010, 1:552-562.

34. Giiselinck I, Van Broeckhoven C, Cruts M: Granulin mutations associated with frontotemporal lobar degeneration and related disorders: an update. Hum Mutat 2008, 29:1373-1386.

35. Alzheimer Disease \& Frontotemporal Dementia Mutation Database [http://www.molgen.ua.ac.be/ftdmutations/]

36. Gijselinck I, van der Zee J, Engelborghs S, Goossens D, Peeters K, Mattheijssens M, Corsmit E, Del-Favero J, De Deyn PP, Van Broeckhoven C, Cruts M: Progranulin locus deletion in frontotemporal dementia. Hum
Mutat 2008, 29:53-58

37. Mukherjee O, Pastor P, Cairns NJ, Chakraverty S, Kauwe JS, Shears S, Behrens MI, Budde J, Hinrichs AL, Norton J, Levitch D, Taylor-Reinwald L, Gitcho M, Tu PH, Tenenholz Grinberg L, Liscic RM, Armendariz J, Morris JC, Goate AM: HDDD2 is a familial frontotemporal lobar degeneration with ubiquitinpositive, tau-negative inclusions caused by a missense mutation in the signal peptide of progranulin. Ann Neurol 2006, 60:314-322.

38. Rademakers $R$, Rovelet-Lecrux $A$ : Recent insights into the molecular genetics of dementia. Trends Neurosci 2009, 32:451-461.

39. Bernardi L, Tomaino C, Anfossi M, Gallo M, Geracitano S, Costanzo A, Colao R, Puccio G, Frangipane F, Curcio SA, Mirabelli M, Smirne N, lapaolo D, Maletta RG, Bruni AC: Novel PSEN1 and PGRN mutations in early-onset familial frontotemporal dementia. Neurobiol Aging 2009, 30:1825-1833.

40. Brouwers N, Sleegers K, Engelborghs S, Maurer-Stroh S, Gijselinck I, van der Zee J, Pickut BA, Van den Broeck M, Mattheijssens M, Peeters K, Schymkowitz J, Rousseau F, Martin JJ, Cruts M, De Deyn PP, Van Broeckhoven C: Genetic variability in progranulin contributes to risk for clinically diagnosed Alzheimer disease. Neurology 2008, 71:656-664.

41. Finch N, Baker M, Crook R, Swanson K, Kuntz K, Surtees R, Bisceglio G, RoveletLecrux A, Boeve B, Petersen RC, Dickson DW, Younkin SG, Deramecourt V, Crook J, Graff-Radford NR, Rademakers R: Plasma progranulin levels predict progranulin mutation status in frontotemporal dementia patients and asymptomatic family members. Brain 2009, 132:583-591.

42. Shankaran SS, Capell A, Hruscha AT, Fellerer K, Neumann M, Schmid B, Haass C: Missense mutations in the progranulin gene linked to frontotemporal lobar degeneration with ubiquitin-immunoreactive inclusions reduce progranulin production and secretion. J Biol Chem 2008, 283:1744-1753.

43. van der Zee J, Le Ber I, Maurer-Stroh S, Engelborghs S, Gijselinck I, Camuzat A, Brouwers N, Vandenberghe R, Sleegers K, Hannequin D, Dermaut B, Schymkowitz J, Campion D, Santens P, Martin JJ, Lacomblez L, De Pooter T, Peeters K, Mattheijssens M, Vercelletto M, Van den Broeck M, Cruts M, De Deyn PP, Rousseau F, Brice A, Van Broeckhoven C: Mutations other than null mutations producing a pathogenic loss of progranulin in frontotemporal dementia. Hum Mutat 2007, 28:416.

44. Wang J, Van Damme P, Cruchaga C, Gitcho MA, Vidal JM, Seijo-Martinez M, Wang L, Wu JY, Robberecht W, Goate A: Pathogenic cysteine mutations affect progranulin function and production of mature granulins. J Neurochem 2010, 112:1305-1315.

45. Rademakers R, Eriksen JL, Baker M, Robinson T, Ahmed Z, Lincoln SJ, Finch N, Rutherford NJ, Crook RJ, Josephs KA, Boeve BF, Knopman DS, Petersen RC, Parisi JE, Caselli RJ, Wszolek ZK, Uitti RJ, Feldman H, Hutton ML, Mackenzie IR, Graff-Radford NR, Dickson DW: Common variation in the miR-659 bindingsite of GRN is a major risk factor for TDP43-positive frontotemporal dementia. Hum Mol Genet 2008, 17:3631-3642.

46. Rollinson S, Rohrer JD, van der Zee J, Sleegers K, Mead S, Engelborghs S, Collinge J, De Deyn PP, Mann DM, Van Broeckhoven C, Pickering-Brown SM: No association of PGRN 3'UTR rs5848 in frontotemporal lobar degeneration. Neurobiol Aging 2011, 32:754-755,

47. Simon-Sanchez J, Seelaar H, Bochdanovits Z, Deeg DJ, van Swieten JC, Heutink P: Variation at GRN 3'-UTR rs5848 is not associated with a risk of frontotemporal lobar degeneration in Dutch population. PLoS One 2009, 4:e7494.

48. Dickson DW, Baker M, Rademakers R: Common variant in GRN is a genetic risk factor for hippocampal sclerosis in the elderly. Neurodegener Dis 2010, 7:170-174.

49. Lee MJ, Chen TF, Cheng TW, Chiu MJ: rs5848 variant of progranulin gene is a risk of Alzheimer's disease in the Taiwanese population. Neurodegener Dis 2011, 8:216-220.

50. Viswanathan J, Makinen P, Helisalmi S, Haapasalo A, Soininen H, Hiltunen M: An association study between granulin gene polymorphisms and Alzheimer's disease in Finnish population. Am J Med Genet B Neuropsychiatr Genet 2009, 150B:747-750.

51. Sleegers K, Brouwers N, Maurer-Stroh S, van Es MA, Van Damme P, van Vught PW, van der Zee J, Serneels S, De Pooter T, Van den Broeck M, Cruts M, Schymkowitz J, De Jonghe P, Rousseau F, van den Berg LH, Robberecht W, Van Broeckhoven C: Progranulin genetic variability contributes to amyotrophic lateral sclerosis. Neurology 2008, 71:253-259.

52. Galimberti D, Fenoglio C, Cortini F, Serpente M, Venturelli E, Villa C, Clerici F, Marcone A, Benussi L, Ghidoni R, Gallone S, Scalabrini D, Restelli I, Boneschi FM, Cappa S, Binetti G, Mariani C, Rainero I, Giordana MT, Bresolin N, Scarpini E: GRN variability contributes to sporadic frontotemporal lobar 
degeneration. J Alzheimers Dis 2010, 19:171-177.

53. Ryan CL, Baranowski DC, Chitramuthu BP, Malik S, Li Z, Cao M, Minotti S, Durham HD, Kay DG, Shaw CA, Bennett HP, Bateman A: Progranulin is expressed within motor neurons and promotes neuronal cell survival. BMC Neurosci 2009, 10:130

54. Tapia L, Milnerwood A, Guo A, Mills F, Yoshida E, Vasuta C, Mackenzie IR, Raymond L, Cynader M, Jia W, Bamji SX: Progranulin deficiency decreases gross neural connectivity but enhances transmission at individual synapses. J Neurosci 2011, 31:11126-11132.

55. Nedachi T, Kawai T, Matsuwaki T, Yamanouchi K, Nishihara M: Progranulin enhances neural progenitor cell proliferation through glycogen synthase kinase 3beta phosphorylation. Neuroscience 2011, 185:106-115.

56. Kleinberger $\mathrm{G}$, Wils $\mathrm{H}$, Ponsaerts $\mathrm{P}$, Joris $\mathrm{G}$, Timmermans JP, Van Broeckhoven C, Kumar-Singh S: Increased caspase activation and decreased TDP-43 solubility in progranulin knockout cortical cultures. J Neurochem 2010, 115:735-747.

57. Xu J, Xilouri M, Bruban J, Shioi J, Shao Z, Papazoglou I, Vekrellis K, Robakis NK: Extracellular progranulin protects cortical neurons from toxic insults by activating survival signaling. Neurobiol Aging 2011, 32:2326.

58. Rosen EY, Wexler EM, Versano R, Coppola G, Gao F, Winden KD, Oldham MC, Martens LH, Zhou P, Farese RV Jr, Geschwind DH: Functional genomic analyses identify pathways dysregulated by progranulin deficiency, implicating wnt signaling. Neuron 2011, 71:1030-1042.

59. Guo A, Tapia L, Bamji SX, Cynader MS, Jia W: Progranulin deficiency leads to enhanced cell vulnerability and TDP-43 translocation in primary neuronal cultures. Brain Res 2010, 1366:1-8.

60. Zhang YJ, Xu YF, Dickey CA, Buratti E, Baralle F, Bailey R, Pickering-Brown S, Dickson D, Petrucelli L: Progranulin mediates caspase-dependent cleavage of TAR DNA binding protein-43. J Neurosci 2007, 27:10530-10534.

61. Dormann D, Capell A, Carlson AM, Shankaran SS, Rodde R, Neumann M, Kremmer E, Matsuwaki T, Yamanouchi K, Nishihara M, Haass C: Proteolytic processing of TAR DNA binding protein- 43 by caspases produces $C-$ terminal fragments with disease defining properties independent of progranulin. J Neurochem 2009, 110:1082-1094.

62. Carrasquillo MM, Nicholson AM, Finch N, Gibbs JR, Baker M, Rutherford NJ, Hunter TA, DeJesus-Hernandez M, Bisceglio GD, Mackenzie IR, Singleton A, Cookson MR, Crook JE, Dillman A, Hernandez D, Petersen RC, Graff-Radford NR, Younkin SG, Rademakers R: Genome-wide screen identifies rs646776 near sortilin as a regulator of progranulin levels in human plasma. Am J Hum Genet 2010, 87:890-897.

63. Hu F, Padukkavidana T, Vaegter CB, Brady OA, Zheng Y, Mackenzie IR, Feldman $\mathrm{HH}$, Nykjaer A, Strittmatter SM: Sortilin-mediated endocytosis determines levels of the frontotemporal dementia protein, progranulin. Neuron 2010, 68:654-667.

64. Willnow TE, Petersen CM, Nykjaer A: VPS10P-domain receptors - regulators of neuronal viability and function. Nat Rev Neurosci 2008, 9:899-909.

65. Zheng Y, Brady OA, Meng PS, Mao Y, Hu F: C-terminus of progranulin interacts with the beta-propeller region of sortilin to regulate progranulin trafficking. PLoS One 2011, 6:e21023.

66. Hermey G: The Vps10p-domain receptor family. Cell Mol Life Sci 2009, 66:2677-2689

67. Petersen CM, Nielsen MS, Nykjaer A, Jacobsen L, Tommerup N, Rasmussen $\mathrm{HH}$, Roigaard H, Gliemann J, Madsen P, Moestrup SK: Molecular identification of a novel candidate sorting receptor purified from human brain by receptor-associated protein affinity chromatography. J Biol Chem 1997, 272:3599-3605

68. Tang W, Lu Y, Tian QY, Zhang Y, Guo FJ, Liu GY, Syed NM, Lai Y, Lin EA, Kong L, Su J, Yin F, Ding AH, Zanin-Zhorov A, Dustin ML, Tao J, Craft J, Yin Z, Feng JQ, Abramson SB, YU XP, Liu CJ: The growth factor progranulin binds to TNF receptors and is therapeutic against inflammatory arthritis in mice. Science 2011, 332:478-484.

69. Kayasuga Y, Chiba S, Suzuki M, Kikusui T, Matsuwaki T, Yamanouchi K, Kotaki H, Horai R, Iwakura Y, Nishihara M: Alteration of behavioural phenotype in mice by targeted disruption of the progranulin gene. Behav Brain Res 2007 . 185:110-118.
70. Ahmed Z, Sheng H, Xu YF, Lin WL, Innes AE, Gass J, Yu X, Wuertzer CA, Hou H, Chiba S, Yamanouchi K, Leissring M, Petrucelli L, Nishihara M, Hutton ML, McGowan E, Dickson DW, Lewis J: Accelerated lipofuscinosis and ubiquitination in granulin knockout mice suggest a role for progranulin in successful aging. Am J Pathol 2010, 177:311-324.

71. Yin F, Banerjee R, Thomas B, Zhou P, Qian L, Jia T, Ma X, Ma Y, ladecola C, Beal MF, Nathan C, Ding A: Exaggerated inflammation, impaired host defense, and neuropathology in progranulin-deficient mice. J Exp Med 2010, 207:117-128.

72. Yin F, Dumont M, Banerjee R, Ma Y, Li H, Lin MT, Beal MF, Nathan C, Thomas B, Ding A: Behavioral deficits and progressive neuropathology in progranulin-deficient mice: a mouse model of frontotemporal dementia. FASEB J 2010, 24:4639-4647.

73. Kao AW, Eisenhut RJ, Martens LH, Nakamura A, Huang A, Bagley JA, Zhou P, de Luis A, Neukomm L, Cabello J, Farese RV Jr, Kenyon C:

A neurodegenerative disease mutation that accelerates the clearance of apoptotic cells. Proc Natl Acad Sci U S A 2011, 108:4441-4446.

74. Chitramuthu BP, Baranowski DC, Kay DG, Bateman A, Bennett HP: Progranulin modulates zebrafish motoneuron development in vivo and rescues truncation defects associated with knockdown of Survival motor neuron 1. Mol Neurodegener 2010, 5:41.

75. Cenik B, Sephton CF, Dewey CM, Xian X, Wei S, Yu K, Niu W, Coppola G, Coughlin SE, Lee SE, Dries DR, Almeida S, Geschwind DH, Gao FB, Miller BL, Farese RV Jr, Posner BA, Yu G, Herz J: Suberoylanilide hydroxamic acid (vorinostat) up-regulates progranulin transcription: rational therapeutic approach to frontotemporal dementia. J Biol Chem 2011, 286:16101-16108.

76. Capell A, Liebscher S, Fellerer K, Brouwers N, Willem M, Lammich S, Gijselinck I, Bittner T, Carlson AM, Sasse F, Kunze B, Steinmetz H, Jansen R, Dormann D, Sleegers K, Cruts M, Herms J, Van Broeckhoven C, Haass C: Rescue of progranulin deficiency associated with frontotemporal lobar degeneration by alkalizing reagents and inhibition of vacuolar ATPase. J Neurosci 2011, 31:1885-1894.

77. Van Deerlin VM, Sleiman PM, Martinez-Lage M, Chen-Plotkin A, Wang LS, Graff-Radford NR, Dickson DW, Rademakers R, Boeve BF, Grossman M, Arnold SE, Mann DM, Pickering-Brown SM, Seelaar H, Heutink P, van Swieten JC, Murrell JR, Ghetti B, Spina S, Grafman J, Hodges J, Spillantini MG, Gilman S, Lieberman AP, Kaye JA, Woltjer RL, Bigio EH, Mesulam M, Al-Sarraj S, Troakes C, et al: Common variants at 7p21 are associated with frontotemporal lobar degeneration with TDP-43 inclusions. Nat Genet 2010, 42:234-239.

78. Finch N, Carrasquillo MM, Baker M, Rutherford NJ, Coppola G, DejesusHernandez M, Crook R, Hunter T, Ghidoni R, Benussi L, Crook J, Finger E, Hantanpaa KJ, Karydas AM, Sengdy P, Gonzalez J, Seeley WW, Johnson N, Beach TG, Mesulam M, Forloni G, Kertesz A, Knopman DS, Uitti R, White CL, 3rd, Caselli R, Lippa C, Bigio EH, Wszolek ZK, Binetti G, et al:: TMEM106B regulates progranulin levels and the penetrance of FTLD in GRN mutation carriers. Neurology 2011, 76:467-474.

79. Cruchaga C, Graff C, Chiang HH, Wang J, Hinrichs AL, Spiegel N, Bertelsen S, Mayo K, Norton JB, Morris JC, Goate A: Association of TMEM106B gene polymorphism with age at onset in granulin mutation carriers and plasma granulin protein levels. Arch Neurol 2011, 68:581-586.

80. Rollinson S, Mead S, Snowden J, Richardson A, Rohrer J, Halliwell N, Usher S, Neary D, Mann D, Hardy J, Pickering-Brown S: Frontotemporal lobar degeneration genome wide association study replication confirms a risk locus shared with amyotrophic lateral sclerosis. Neurobiol Aging 2011, 32:758 e751-e757.

doi:10.1186/alzrt102

Cite this article as: Nicholson AM, et al.: Progranulin axis and recent developments in frontotemporal lobar degeneration. Alzheimer's Research \& Therapy 2012, 4:4. 